\title{
YŪḤANNĀ IBN SARĀBIYŪN: FURTHER STUDIES INTO THE TRANSMISSION OF HIS WORKS
}

\author{
PETER E. PORMANN* \\ Manfredo Ullmann, magistro meo, \\ pro sua erga me liberalitate \\ necnon humanitate \\ grato animo dedicatum
}

Ibn Sarābiyūn is one of the last exponents of classical Syriac medical writing, and one of the most influential authors for the development of medical theory and practice in late ninthcentury Baghdad in particular, and for the Arabic medical tradition in general. During the last thirty years, three important studies have been published regarding the life and work of Ibn Sarābiyūn, each of which dealing with a different aspect of the transmission of this important author's œuvre. ${ }^{1}$ Likewise, during the last twenty-five years, a number of texts associated with Ibn Sarābiyūn's works have been edited, allowing us today to shed new light on the relation between the original Syriac and the numerous translations into Arabic, Latin and

* I would like to record my gratitude to Prof. Ch. Burnett, Dr E. Savage-Smith, Prof. M. Ullmann, and the anonymous referee, who read an earlier draft of this article and made invaluable comments. I am particularly indebted to Prof. R. Kruk, Prof. A. van der Heide, Dr H. van de Velde and Prof. J. J. Witkam, who assisted me in different ways during my time in Leiden. This research was made possible thanks to the Warden and Fellows of Merton College, Oxford, who elected me to a Junior Research Fellowship. I finally wish to thank the staff at the Oriental Reading Room of the Bodleian Library, which has become my second home over these last years, and especially the Keeper of the Oriental Collections, L. Forbes, who has facilitated my research there tremendously.

1 M. Ullmann, "Yūḥannā ibn Sarābiyūn Untersuchungen zur Überlieferungsgeschichte seiner Werke", Medizinhistorisches Journal, VI, 4 (1971): 278-96; L. Richter-Bernburg, "Pseudo-T̄ābit, Pseudo-Rāzī, Yuhannā ibn Sarābiyūn”, Der Islam, 60 (1983): 48-77; and G. Troupeau, "Du syriaque au latin par l'intermédiaire de l'arabe: le Kunnāš de Yūḥannā ibn Sarābiyūn", Arabic Sciences and Philosophy, 4, 2 (1994): 267-78. Later scholars find themselves often in the situation of standing on the shoulders of giants; this is also my case: I am heavily indebted to the work of Ullmann, Richter-Bernburg and Troupeau. But just as they provide the foundation of this research, it is possible to go beyond them and rectify some of their assumptions; this, of course, does not detract from the great esteem one has for their work. 
Hebrew. Furthermore, through analysing and comparing a number of manuscripts containing different parts of Ibn Sarābiyūn's work which have not hitherto been considered together, progress can be made towards answering the question how Ibn Sarābiyūn was translated and used during the medieval period.

The present contribution is divided into three parts. Firstly, the question of Ibn Sarābiyūn's biography and bibliography will be tackled. It is surprising how much uncertainty still exists today as to when this author lived and what he wrote. Secondly, the most famous book by Ibn Sarābiyūn, the Small Compendium on Medicine, and the question of its transmission will be discussed. Thirdly, his Large Compendium will be the focus of our attention; in this part, Arabic fragments will be edited for the first time and used for a comparison of the Small with the Large Compendium.

I

Very few things are known about the life of Ibn Sarābiyūn from medieval bio-bibliographic sources. In the Fihrist of Ibn al-Nadīm (written in $987 \mathrm{CE}^{2}$ ) we are told: ${ }^{3}$

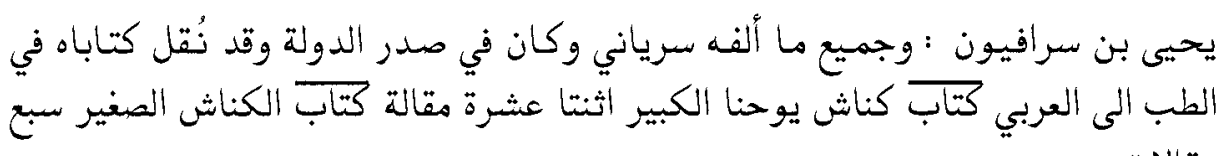

Yahyā ibn Sarāfiyūn: All he wrote was Syriac. He lived at the beginning of the ['Abbāsid] dynasty. His two books on medicine were translated into Arabic: The Large Compendium (kunnāš) of Yūhannā, ${ }^{4}$ which consists of twelve maqālas. The Small Compendium, [in] seven maqālas.

Al-Qifți (d. 1248) gives a similar account, while Ibn Abī Ușaybi'a, provides us with more information. He mentions different translations of the Small Compendium, namely that by Mūsā ibn Ibrāhīm al-Hadītī, and that by Bar Bahlūl. ${ }^{5}$ The latter quotes Ibn Sarābiyūn on a number of occasions in his

2 All dates, unless otherwise indicated, refer to the Common Era (CE).

${ }^{3}$ Ibn al-Nadīm, Kitāb al-Fihrist, ed. G. Flügel, 2 vols. (Leipzig, 1871-2), p. 296, 1. 7-9; all translations, unless otherwise stated, are my own.

4 "Yahyā" and "Yūhannā" are two variant forms of the same name "John"

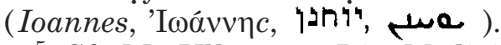

${ }^{5}$ Cf. M. Ullmann, Die Medizin im Islam, HO 1. Abt. Erg. 6.1 (Leiden etc., 1970), p. 102; see also below pp. 239-40. 
lexicon, and this is our only source for what meagre fragments we have of the Syriac text. ${ }^{6}$

All these Arabic bio-bibliographers agree that Ibn Sarābiyūn lived in the early period of the 'Abbāsid dynasty, that is to say in the second half of the eighth century. M. Ullmann and others have argued that since Ibn Sarābiyūn quotes some later authors such as Hunayn ibn Ishāq (d. ca. 877) and Sābūr ibn Sahl (d. 869), he must have lived in the second half of the ninth century, and that the information contained in the biobibliographical tradition is erroneous. ${ }^{7}$ Troupeau dismissed this argument, saying that the later quotations could have been interpolated by the Arabic translators, something Ullmann thought was unlikely. ${ }^{8}$ There is another, stronger argument for dating Ibn Sarābiyūn to second half of the ninth rather than eighth century, which Ullmann was the first to invoke and Troupeau did not discuss: Ibn Sarābiyūn revised (ișlāh) Sābūr ibn Sahl's Dispensatory, which means that he is later than an author who certainly lived and wrote in the ninth century. ${ }^{9}$ Furthermore, H. Lehmann proposed 873 as a date for the composition of the [Small] Compendium; ${ }^{10}$ yet although he promised to substantiate this date, he has never done so in

${ }^{6}$ For example under the entry Lol;, Hassano Bar Bahlule, ed. R. Duval, 3 vols. (Paris, 1901), col. 1586, 3] we find the following citation:

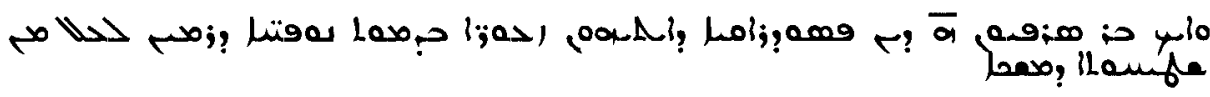

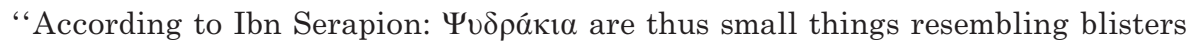
arising above the surface of the skin."

Yet, it is not even clear from which work by Ibn Sarābiyūn Bar Bahlūl quotes here.

${ }^{7}$ Cf. Ullmann, "Sarābiyūn", pp. 278-80, following e.g. L. Leclerc, Histoire de la médecine arabe, 2 vols. (Paris, 1876), vol. 1, pp. 115-16.

8 Troupeau, "Du syriaque ...", p. 269: "Or cet argument ne me paraît absolument pas convaincant, car ces citations de médecins postérieurs à Ibn Sérapion, ont très bien pu être introduites dans son Kunnāš par les traducteurs du x siècle."; Ullmann, "Sarābiyūn", p. 279: "Diese Zitate kann man kaum als spätere Interpolationen betrachten."

9 Ullmann, "Sarābiyūn", p. 279; cf. R. Degen, M. Ullmann, “Zum Dispensatorium des Sābūr ibn Sahl", Welt des Orient, 7 (1973-4): 241-58, esp. pp. 253-4, and O. Kahl, Sābūr ibn Sahl. Dispensatorium parvum (al-Aqrābāāhīn al-șaghīr) (Leiden etc., 1994), pp. 17-18.

io See Ullmann, Medizin, p. 102. The reference is to Lehmann's review of G. Sobhy's The Book of Al Dakhîra (Cairo, 1928) in Orientalisch Literaturzeitung, 11 (1929): 869-70 [repr. in F. Sezgin, Tāait ibn Qurra (d. 288/901): Texts and Studies, Publications of the Institute for the History of Arabic-Islamic Science: Islamic Medicine 32 (Frankfurt, 1996), pp. 277-9]. 
print. Apart from Lehmann's unverifiable statement, the other two reasons for dating Ibn Sarābiyūn to the ninth rather than the eighth century are persuasive in their own right, and, $a$ fortiori, are convincing, when taken together: (1) the sheer amount of quotations from ninth-century authors makes an interpolation by a translator or redactor unlikely; and (2) if Ibn Sarābiyūn revised Sābūr ibn Sahl's work, he must a least be contemporaneous.

Another conundrum which still occupies the minds of many scholars, especially those concerned with medieval Latin medicine, is that of "Serapion Iunior", a younger Ibn Sarābiyūn, to be distinguished from a "Serapion Senior", the Ibn Sarābiyūn discussed here and author of the Small and Large Compendium. There are two aspects to this problem. Firstly, we read in Arabic bio-bibliographical sources that a Dāwūd ibn Sarābiyūn, who lived in the late eighth century, is the brother of our Yūhannā ibn Sarābiyūn. ${ }^{11}$ We have already seen that this is impossible from a chronological point of view: Yūhannā ibn Sarābiyūn lived in the ninth century. So whatever the historical truth about this Dāwūd ibn Sarābiyūn might be, if he lived in the eighth century, he cannot be the brother of Yūhannā ibn Sarābiyūn. ${ }^{12}$ The notion of two Ibn Sarābiyūn brothers, Dāwūd and Yūhannā, was erroneously combined with another misunderstanding.

We have Gerard of Cremona's Latin translation of Ibn Sarābiyun's Small Compendium, the editio princeps of which is entitled: Breviarium medicinae. ${ }^{13}$ But there was another Arabic medical text translated into Latin around 1290 by the Jew Abraham of Tortuso and commonly attributed to a Serapion, namely the Liber aggregatus in medicinis simplicibus. ${ }^{14}$ Already in the Middle Ages it became apparent that the Liber aggregatus is more recent in date than the Breviarium medicinae,

${ }^{11}$ Cf. Ullmann, "Sarābiyūn”, p. 279; al-Qifțī, Ta'rīh al-ḥukamā', ed. J. Lippert

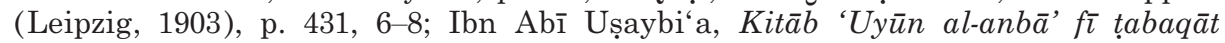
al-ațibbā', ed. A. Müller, 2 vols. (Cairo and Königsberg, 1884), vol. 1, p. 109, 17-22 (quoted infra p. 239).

${ }_{12}$ Ullmann provided a possible explanation for this error, cf. ibid.

13 (Venice, 1479); cf. W. Osler, Incunabula Medica: a Study of the Earliest Printed Medical Books, 1467-1480 (Oxford, 1923), p. 110, no. 174; Ullmann, "Sarābiyūn", p. 282, n. 29 is incorrect.

${ }^{14}$ Cf. P. Dilg, "The Liber aggregatus in medicinis simplicibus of PseudoSerapion: An influential work of medical Arabism", in Ch. Burnett, A. Contadini (eds.), Islam and the Italian Renaissance, Warburg Institute Colloquia 5 (London, 1999), pp. 221-31; cf. Ostler, ibid., no. 173. 
and it was therefore attributed to a "Serapion Iunior" while the author of the Breviarium medicinae became known as the "Serapion Senior". ${ }^{15}$ M. Ullmann argued that this Liber aggregatus de simplicibus medicinis could not have been written before the end of the thirteenth century because of similarities between it and the $G \bar{a} m i^{\text {' }}$ by Ibn al-Baytar. ${ }^{16}$ In the meantime, L. F. Aguirre De Cárcer edited Ibn Wāfid's Kitāb al-Adwiya al-mufrada (Book on Simple Drugs), ${ }^{17}$ which J. C. Villaverde Amieva demonstrated is the Arabic original of the Latin Liber aggregatus. ${ }^{18}$ Since Villaverde Amieva did this in a review not readily available to scholars, at least in the Anglo-Saxon world, I would like to rehearse his main argument. The prologue (as well as the rest) of Ibn Wāfid's work is identical to that contained in the Liber aggregatus as the comparison of the first sentence in the two texts shows ${ }^{19}$ :

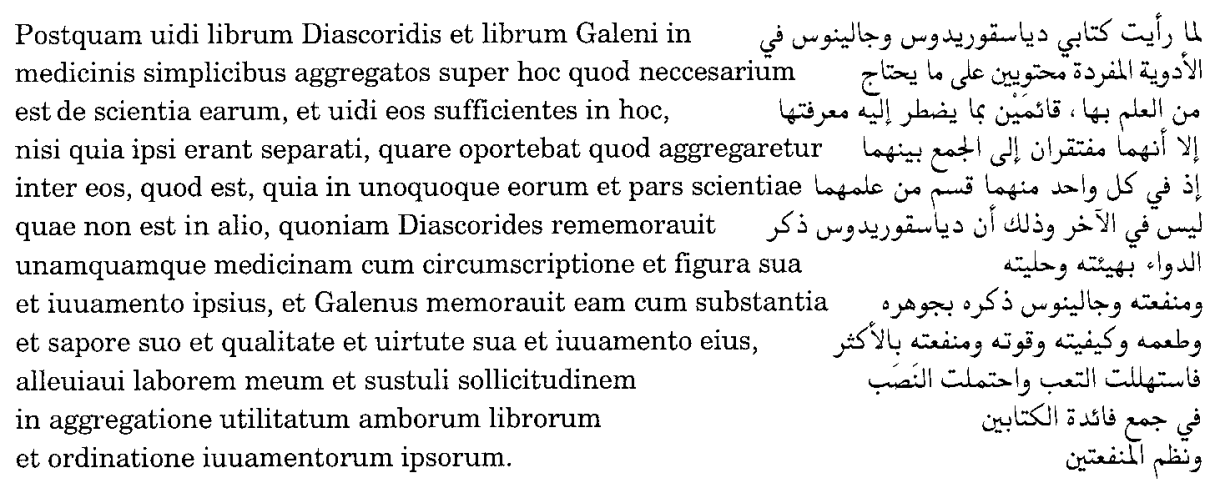
Translation of the Arabic: Since I saw that the two books on simple drugs by Dioscorides and Galen contain the knowledge ['ilm] about them [sc. the simple drugs] which one needs, and provide [all] the information about them which one ought to have, except that they require to be combined, for in each one of them there is a part of the science about them [sc. the simple drugs] which is not found in the other (for most of the time Dioscorides gives the form, outer appearance and use of each drug, while Galen gives the substance, taste, quality, potency and use), I made the task easier and took the labour upon me to gather together [all] that is excellent in these two books and to organise [the material according to] the utility in them.

15 Dilg, “The Liber aggregatus", p. 223.

16 Ullmann, Medizin, pp. 283-4.

17 Ibn Wāfid (m. 460/1067). Kitāb al-Adwiya al-mufrada (Libro de los medicamentos simples), Edición, traducción, notas y glosarios, 2 vols. (Madrid, 1995); there is also a new edition by A. H. Basağ (Beirut, 2000).

18 Aljamía, 9 (1997): 112-18; cf. Ullmann, Medizin, p. 273.

19 Ibid., pp. 114-15; sig. a 2 r (Venice, 1479); I changed the orthography of the Latin and the Arabic slightly. 
There can therefore be no doubt, as Villaverde Amieva states, that the alleged Serapion Iunior, author of the Liber aggregatus, is no other than Ibn Wāfid. ${ }^{20}$ Furthermore, a comparison between the Latin translation and the edition by A. H. Basağ confirms this analysis. ${ }^{21}$ Likewise, whatever the historical value of the information about Dāwūd ibn Sarābiyūn, he is not the brother of the Yūhannā ibn Sarābiyūn discussed here. The distinction between a Younger and Elder Serapion is therefore erroneous and should be abandoned. Yūhannā ibn Sarābiyūn lived in the second half of the ninth century and wrote two works, the Small Compendium and the Large Compendium.

Before we come to these two works, it is necessary to deal with another Ibn Sarābiyūn whom one might confuse with, or relate to, the Yūhannā ibn Sarābiyūn discussed here. He is one Ibn Sarābiyūn ibn Ibrāhīm, the alleged author of a Kitāb al-Fușūl al-muhimma fī tibb al-a'imma (Book of Important Chapters on the Medicine of the Masters), contained in a unique manuscript, Oxford, Bodleian Library, Oriental Collections, MS Hunt. 461, and described and partly edited by

${ }^{20}$ Ibid., p. 113: “. . . el cotejo del prólogo ... no dejaba lugar a dudas, y ponía de manifiesto que la obra atribuida a Serapion es inequívocamente una traducción del Kitāb al-adwiya al-mufrada de Ibn Wāfid."

${ }^{21}$ Unfortunately, this edition (see above n. 17), which is based on an unnamed manuscript, is incomplete; cf. ibid., p. 3:

$$
\text { ولكن النسخة التي بين أيدينا - على ما يبدو - هي اختصار عن الأصل أو أنها ناقصة. }
$$

In fact, it breaks off at the description of sorrel (rībās; rumex L. and Var.):

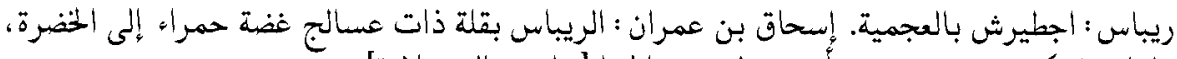

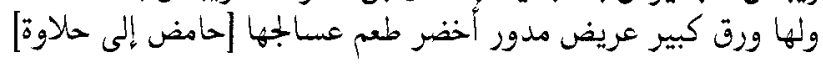

Sorrel ( $r \bar{\imath} b \bar{a} s)$ : 'ǧtyrš (acedera) in the vernacular [i.e. aljamiado, Spanish]. Ishāa ibn 'Imrān: sorrel is a plant having fresh shoots which are red and slightly green; its leaves are big, broad, round and green; the taste of its shoots is pungent and slightly sweet...

corresponding to [Lyons, 1525, fol. 157rb1-6]:

De Ribes. Ribes. Isaac eben Amaram. Ribes est planta habens capreolos recentes rubeos ad uiriditatem tendentes et habet folia magna lata rotunda uiridia; et habet grana quorum sapor est dulcis cum acetositate ...

"Mahamed eben ririfus", mentioned by Ullmann (Medizin, p. 283), is the commentator of the Centriloquium, i.e. Aḥmad ibn Yūsuf ibn Ibrāhīm ibn al-Dāya (d. $951 \mathrm{CE}$ ); cf. GAL S I, p. 229. The similarity between the quotation by this Ibn al-Dāya in the Liber aggregatus and Ibn al-Bayțar seems to be based upon the fact that Ibn al-Bayțar uses Ibn al-Wāfid quite extensively. 
M. Ullmann. ${ }^{22}$ Nothing is known about this author, but since he quotes, among others, Ibn Sīnā (980-1037), he cannot have lived earlier than the eleventh century, and he should not be confused with Yūhannā ibn Sarābiyūn. ${ }^{23}$

II

In the great fire of the Escorial in the year 1671, the only two complete copies of Ibn Sarābiyūn's Small Compendium were lost, as well as two partial copies. Today, we are left with a number of fragments, some of which are substantial, which allow us to regain more than half of the Arabic version of this work. Yet, the transmission of the Small Compendium is problematic not only because of its fragmentary nature. It was so popular that it was translated on a number of occasions by different people. Ibn Abī Ușaybi'a gives the following report about the translations ${ }^{24}$ :

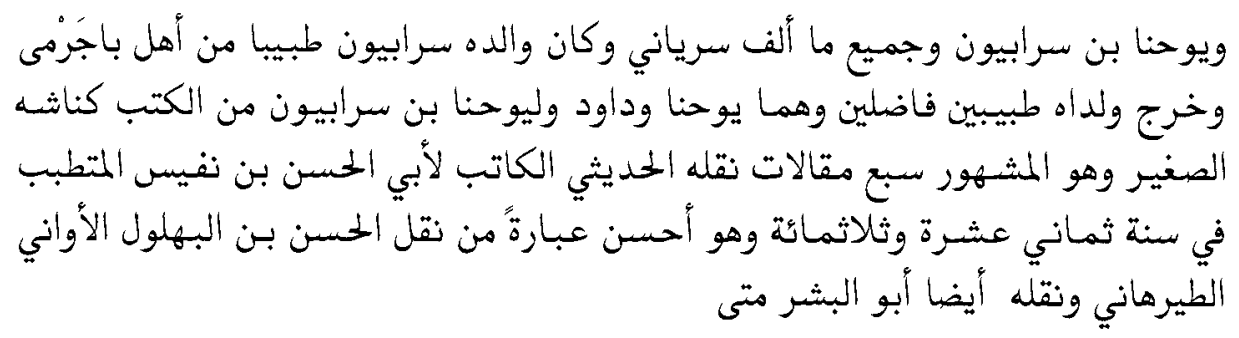

Yūḥannā ibn Sarābiyūn. All he wrote was in Syriac. His father Sarābiyūn was a physician from Bāğarmā. ${ }^{25}$ His [i.e. the father's] two sons became both outstanding physicians; they were: Yūḥannā and Dāwūd; Yūhannā ibn Sarābiyūn wrote the following books: The Small

${ }^{22}$ M. Ullmann, Rufus von Ephesos: Krankenjournale (Wiesbaden, 1978); the manuscripts is described in a very detailed and comprehensive fashion in E. Savage-Smith, Arabic Manuscripts on Medicine and Related Topics, vol. 1 of: C. Wakefield (ed.), A New Catalogue of Arabic Manuscripts in the Bodleian Library, Oxford (Oxford, 2004), forthcoming.

${ }^{23}$ Ibid., p. 12; cf. Ullmann, "Sarābiyūn", p. 296; space does not permit to discuss all the various spurious references, for instance, to "serapino"

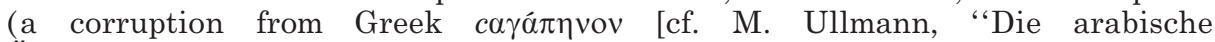
Überlieferung der Schriften des Rufus von Ephesos", in Aufstieg und Niedergang der römischen Welt, II 37.2, 1293-1349, 1301]) or "Saraphies" (denoting Serapion of Alexandria [cf. Ch. Burnett, D. Pingree (eds.), The Liber Aristotilis or Hugo of Santalla (London, 1997), p. 3]).

${ }_{24}^{24}$ I, 109, 17-23; cf. Ullmann, "Sarābiyūn”, pp. 280-1, and Troupeau, "Du syriaque ...", pp. 270-1.

${ }_{25}$ According to Troupeau, "Du syriaque ...", p. 268, the province called in Syriac دماه; $\mathbf{\Delta}$; cf. $E I^{2}$ s.v. Bādjjarmā. 
Compendium, the famous one, in seven maqālas, was translated by [Mūsā ibn Ibrāhīm] al-Hadītī, the secretary for Abū al-Hasan ibn Nafīs, the physician, in the year 318 [AH / $930 \mathrm{CE}$ ]. This is a more idiomatic translation than that by al-Hasan ibn al-Bahlūl [sic] al-Awān̄ al-Ṭīrhānī. It was also translated by Abū Bišr Mattā.

In the following, I shall first review these three translators, and then describe the extant Arabic manuscripts. Although I shall rehearse some of the arguments found in the previous scholarly work, ${ }^{26}$ it is nonetheless essential to look at the evidence again, because new material has come to light that makes a fresh interpretation possible.

Of the first translator mentioned by Ibn Abī Ușaybi“a, Mūsā ibn Ibrāhīm al-Hadīț̄, we know nothing other than the information given in this entry. He is also named in two manuscript copies as the translator (see below). Al-Hasan ibn al-Bahlūl al-Awān̄̄ al-Ṭ̂̄rhān̄̄ (fl. 963), the second translator in Ibn Sarābiyūn's list, is none other than Bar Bahlūl, the famous glossographer. He is mostly known for his Syriac lexicon edited by R. Duval ${ }^{27}$ and is the author of a Book of Indications written in Arabic ${ }^{28}$; furthermore, he translated Theophrastus' Meteorology from Syriac into Arabic. ${ }^{29}$ Finally, Abū Bišr Mattā (d. 940) translated, among other things, Aristotle's Poetics. ${ }^{30}$

As mentioned above, the Syriac original version of the Small Compendium is nearly entirely lost for us. ${ }^{31}$ The Arabic manuscripts containing portions of the Small Compendium are the following:

26 Cf. p. 233, n. 1.

27 Lexicon Syriacum, ed. Duval.

${ }^{28}$ Kitāb al-Dalā'il, published in fascimile by F. Sezgin, Publications of the Institute for the History of Arabic-Islamic Science, Series C, vol. 10 (Frankfurt, 1985), and also edited by Y. Habbī (Kuwait, 1987).

${ }^{29}$ Cf. H. Daiber, "The Meteorology of Theophrastus in Syriac and Arabic translation", in W. W. Fortenbaugh, D. Gutas (eds.), Theophrastus, His Psychological, Doxographical, and Scientific Writing, Rutgers University Studies in Classical Humanities 5 (New Brunswick and London, 1992), pp. 166-293; H. Takahashi, "Syriac fragments of Theophrastean meterology and mineralogy", in W. W. Fortenbaugh, G. Wöhrle (eds.), On the Opuscula of Theophrastus (Stuttgart, 2002), pp. 191-224.

30 Ed. J. Tkatsch, Die arabische Übersetzung der Poetik des Aristoteles, 2 vols. (Vienna and Leipzig, 1928/32); cf. W. Heinrichs, Arabische Dichtung und griechische Poetik, Beiruter Texte und Studien 8 (Beirut, 1969), pp. 118-23; G. Endress, art. Mattā b. Yūnus, Abū Bišr in $E I^{2}, 6,844$ b.

31 See above p. 235, n. 6. 
1. Madrid, Escorial, MS 818, fols. 129-135, containing book 1, ch. 1-3 (beginning); abbr. Ea.

2. Paris, BNF, MS 2918 (fonds arabe), fols. 155-170, containing book 3, ch. 30-31, book 4, ch. 1-2 (beginning), 8 (end)-10 (beginning); abbr. $\mathbf{P}$.

3. Madrid, Escorial, MS 852, fol. 39, containing book 4, ch. 23 (end); abbr. Eb.

4. Brussels, Bibliothèque Royale, MS 19891, containing books 5-7; abbr. B.

5. Leiden, MS 2817 (Cod. 2070), containing book 7; abbr. L.

The manuscripts Ea and $\mathbf{L}$ contain information regarding the translator. $\mathbf{E b}$ and $\mathbf{P}$ do not provide any direct indication about the translator since they lack both beginning and colophon. B does have a title and colophon, but does not contain any information about the translation. ${ }^{32}$ In the following, I shall describe $\mathbf{L}$ in greater detail, because this description, not yet undertaken in previous scholarship, yields a number of interesting findings.

$\mathbf{L}$ is written on non-European paper, measuring $18 \times 22.5 \mathrm{~cm}^{2}$, while the text takes up $15 \times 16 \mathrm{~cm}^{2}$, having approximately 14 lines per page. It is written in mostly unvocalised nash which lacks most diacritical points ${ }^{33}$; $r \bar{a}{ }^{\prime}($,$) is sometimes distin-$ guished from zā' (j) through a caron $(j)$. There are rubrics for titles, beginnings of recipes, section headings and so forth. On

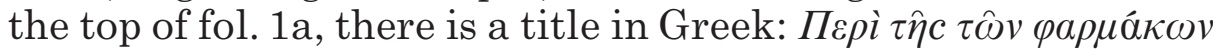

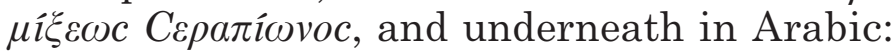

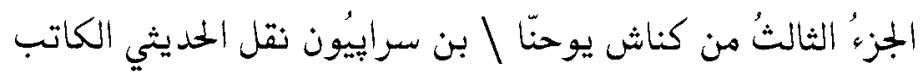

The third part of the kunnāš by Yūḥannā ibn Sarāpiyūn in the translation of al-Hadīîi, the secretary.

Below this in Hebrew: החלק השלישי מספר יוחנן בן סראפיון ברפואות

The third part of the book of Yūḥannan ben Serāpiyōn On Medicine.

${ }^{32}$ For a complete description of this manuscript cf. Ullmann, "Sarābiyūn", pp. 283-4; the order of the folios (according to information provided by Pieter Voorhoeve and reproduced by Ullmann) is as follows: 1-19, 56, 47-55, 20-29, 30-46, 57 ff., the fifth maqāla starting on fol. 1b, the sixth on fol. $29 \mathrm{a}$ and the seventh on fol. $46 \mathrm{~b}$.

${ }^{33}$ This feature led de Goeje to say [Catalogus Codicum orientalium Bibliothecae Academiae Lugduno-Batavae, vol. 5 (Leiden, 1873), p. 322]: "Codex antiquus propter deficientiam punctorum passim lectu difficilis est." 
Underneath this, there is a recipe in Judaeo-Arabic, entitled: צ'מَאד אלחבס ( ضماد الحبس , retentive dressing).

The colophon on the last page (fol. 248a8 ff.) says:

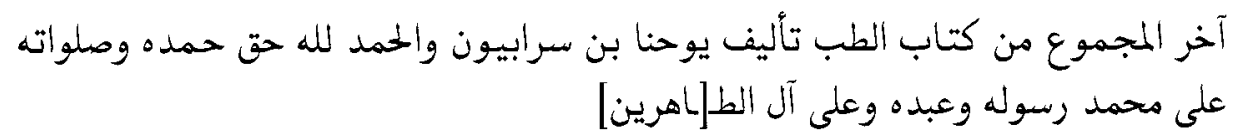

The end of the compilation from the Book of Medicine, written by Ibn Sarābiyūn. Thanks be to God - for it is meet to thank Him - and His blessings on Muhammad, His messenger and servant, and on the righteous people.

Underneath we have an extremely interesting owner's note in Hebrew:

קבלתי מיד רי שמואל ב״ר שלמה המאתי שלוש גולטין [?] של כסף וימשכנתי אליו זה הספר

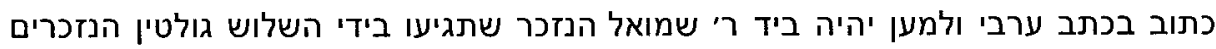

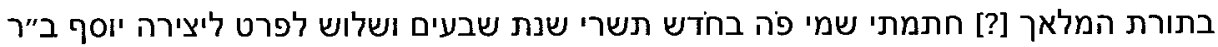

בנבנשתי בתורתי

I received from Rabbi Še mū'ēl ben Rabbī Šelōmō HamMe'ātī three guilders [?] of money; my pledge for him is this book, written in Arabic script. In order that it [this book] be placed in the hands of the aforementioned R. S' $\breve{e}^{\mathrm{e}}$ 'ēl may the aforementioned three guilders [?] come into my hand according to the law of the angel [?]. I signed my name here in the month $t i s ̌ r \bar{l}$ in the year 73 according to the counting from the creation [of the world; i.e. A.M.; corresponding to September 1312 cE]: Yōsēf ben Rabbī Benbeništī.

The actual text starts on fol. $1 \mathrm{~b}$ :

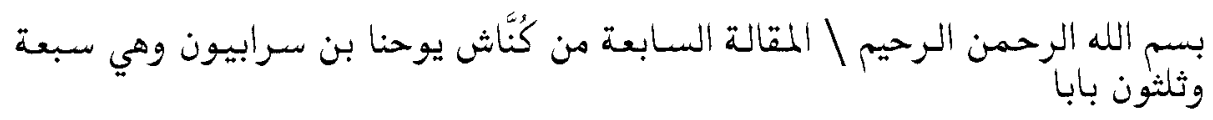

In the name of God, the merciful, the compassionate. The seventh maqāla, of the compendium (kunnāš) by Yūhannā ibn Sarābiyūn, containing 37 chapters $[b \bar{a} b]$.

Then follows the lists of contents, starting as follows:

$$
\begin{aligned}
& \text { آل ما الأثياء التي ينبغي أن يتقدم فيعرفها من كان عازما على تركيب الأدوية بطريق }
\end{aligned}
$$

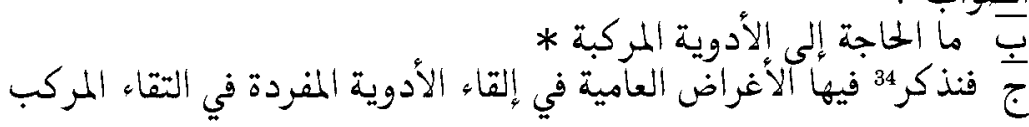


I What are the things that he who is resolved to compound remedies correctly ought to know?

II What need is there for compound remedies?

III In which we discuss the general aims when adding simple drugs in order to compose compound ones?

This information provides us with an interesting insight into the transmission of Ibn Sarābiyūn's Small Compendium. Firstly, the seventh maqāla (section) is called "the third part (ğuz')". This may suggest that the Small Compendium was transmitted in three parts, the first possibly comprising maqāla 1-3, the second maqāla 4-6, and the third maqāla 7, which is by far the longest, although there is the possibility that $\breve{g} u z$ ' (part) simply refers to the parts of a single copy. Furthermore, according to the title, $\mathbf{L}$ contains the translation by Mūsā ibn Ibrāhīm al-Hadītīi, the secretary ( $k \bar{a} t i b)$ which, according to Ibn Abī Ușaybi'a, ${ }^{35}$ was produced in the year 318 / 930. The Hebrew owner's note at the end is interesting in many respects. It testifies to the involvement of the Meati family in medical studies. ${ }^{36}$ But it also gives us a precious terminus ante for the production of the manuscript: "in the month $t i s ̌ r \bar{l}$ of the year 73" refers to tišr 5073 of the Jewish calendar (Anno Mundi) and roughly corresponds to September 1312 CE. ${ }^{37}$

Since $\mathbf{L}$ was translated by al-Hadītīi, the question arises whether $\mathbf{B}$ is based on the same translation. Because both manuscripts contain the text of maqāla seven, we are in the fortunate position to be able to compare the two. Lehmann had already noticed that $\mathbf{B}$ sometimes differs from $\mathbf{L}$ and the Latin translation by Gerard of Cremona (lat. G); for instance, recipes are frequently introduced by the term صنعة (fabrication) in $\mathbf{B}$, while neither $\mathbf{L}$ nor lat. $\mathbf{G}$ have this term or its Latin equivalent. ${ }^{38}$ Yet, generally speaking, both $\mathbf{L}$ and B contain the same translations, as can be seen from the

35 See above pp. 239-40.

36 For Š'mū'ēl ben Rabbī Š̀ lōmō HamMe'ātī cf. A. Wasserstein, Galen's Commentary on the Hippocratic Treatise Airs, Waters, Places (Jerusalem, 1982), esp. appendix II.

37 Assuming that the date refers to the "the small counting"), which only gives the centuries, not the millennia; cf. E. Mahler, Handbuch der jüdischen Chronologie (Leipzig, 1916).

${ }^{38}$ In a letter to Pieter Voorhoeve, dated 24 August 1952 and now kept together with L, p. 5. 
following passage from the beginning of chapter 15 on waterpurging drugs ${ }^{39}$ :

De medicinis soluentibus aquositatem.

Oportet ut administrentur medicinae soluentes aquositatem ei qui habet hydropsim ascitem et mulieribus quibus est fluxus menstruorum alborum et illis quibus sunt ulcera ex quibus egreditur sanies et illis in quorum membris est inflatio ad excitationem et ptisim.

Tubel aeris oportet ut sumatur ex eo aur[eus] unus et d[imidio] cum aqua mellis et oportet ut odoret ${ }^{45}$ post parum acetum ut non euomat ipsum.

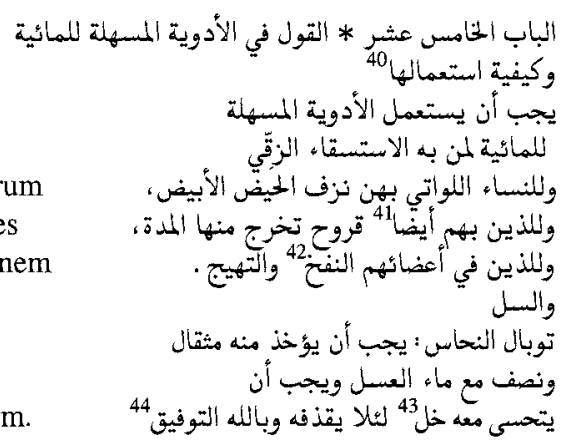

Translation: The fifteenth chapter. Discussion about drugs that alleviate wateriness and how to use them. One ought to use drugs alleviating wateriness for people who have dropsy of the size of a waterskin [istisq $\bar{a}$, ziqqī]; women who suffer from white menstrual haemorrhage; people who also have ulcers exuding pus; and people in whose bodily parts there is flatulence, irritation and atrophy.

Plush-copper. Take one and a half mitqual of it with hydromel; one ought to drink with it [thus B; L and lat. G: "shortly afterwards"] ${ }^{43}$ vinegar, lest one spit it out. Success is through God.

The difference between $\mathbf{B}$ and $\mathbf{L}$, here, consists in $\mathbf{B}$ having three additions which are in italics in the translation, namely وكيفية استعمالها ("and how to use them"), أيضا ("also") and "وبألله التوفيق ("Success is through God"). These additions do not occur in lat. G. In addition, in one instance in the short passage quoted here, $\mathbf{B}$ reflects a textual tradition different from both L and lat. G (cf. n. 43); in other words: B has a variant reading rather than a mere addition. One can speculate whether these additions in $\mathbf{B}$ are those by Bar Bahlūl to which Ea refers. We shall therefore now turn to this manuscript which Troupeau has already described in part. ${ }^{46}$

39 The left-hand column contains lat. G. (fol. $76 \mathrm{vb}-25$ ) and the right-hand column the collated text of $\mathbf{L}$ (fol. 73b4) and $\mathbf{B}$ (fol. 85b -10).

40 g om. L.

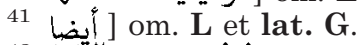

42 [انتخخ

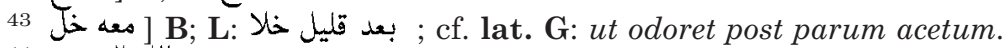

44 om. L.

45 It seems that the lat. odoret (inhale) read a different Arabic text (يثم).

46 "Du syriaque ...", pp. 271-2. 
Ea is a fragment, written in a somewhat stiff nash, which contains the beginning of a copy of Ibn Sarābiyūn's Small Compendium. It is now bound together with other fragments of

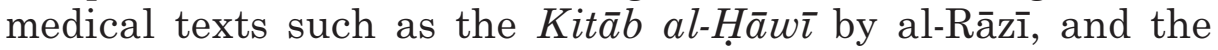
Kitāb al-Malakī by al-Mağūsī. ${ }^{47}$ On the recto of the first folio of the fragment (129a), we read the title of our work: ${ }^{48}$

$$
\text { كناش يوحنا بن سرافيون نقل موسى بن إبرهيم الحديثي وزيادات بن البهلول }
$$

The compendium (kunnāš) of Yūhannā ibn Sarābiyūn, translated by Mūsā ibn Ibrāhīm al-Ḥadītīi, with additions by Ibn al-Bahlūl.

Yet, as Troupeau already noted, the information provided on the verso of this folio, containing the beginning of the actual text, is at first glance contradictory ${ }^{49}$ :

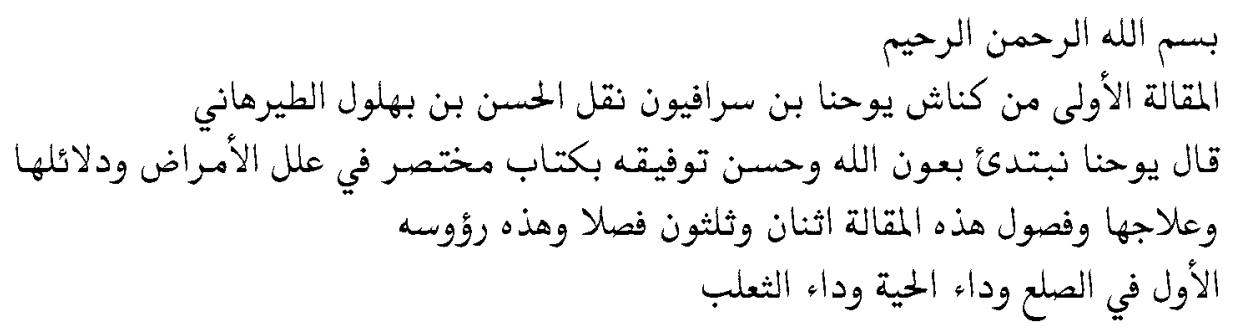

In the name of God, the merciful, the compassionate.

The first maqūla of Yūḥannā ibn Sarābiyūn's Compendium (kunnāas), translated by al-Ḥasan ibn Bahlūl al-Ṭ̄inhānī.

Yūhannā [ibn Sarābiyūn] said: Let us begin - with the help of God and the benefit of His granting success - [to write] an abbreviated book on the causes, indications, and treatment of diseases. The chapters (fușull, sg. fașl) of this maqāla are thirty-two; the following are their headings (ru'üs):

The first on baldness, ophiasis and alopecia.

On the verso, Bar Bahlūl is mentioned as the translator, while on the title recto, al-Hadīîn is alleged to have translated this text, and Bar Bahlūl is said to have contributed additions. One might argue that the apparent contradiction could be explained in the following terms: both the title and the beginning of the treatise mean the same thing, namely that al-Hadītī

\footnotetext{
${ }^{47}$ Cf. H. Derenbourg, H.-P.-J. Renaud, Les manuscrits arabes de l'Escurial, vol. 2.2 (Paris, 1941), pp. 28-30.

48 Fol. 129a; cf. Troupeau, "Du syriaque ...", p. 272.

${ }^{49}$ Fol. 129b, Troupeau, ibid.
} 
originally translated the treatise, and Bar Bahlūl made additions and corrections; on the verso, Bar Bahlūl is named as the translator in a loose sense: he is the last editor, so to speak, of the translation. ${ }^{50}$

We shall return to this problem later, but first of all, let us consider the possible source for the additions alluded to on the title page of Ea. In order to do so, we shall compare the beginning of the first chapter in $\mathbf{E a}$ and lat. $\mathbf{G}^{51}$ :

Capitulum primum de caluitio et alopecia, et tyria.

Aegritudines istae a duabus eueniunt causis, sicut optimus nos docuit Galenus:

quarum una est priuatio humiditatis, quae nutrit capillos, et secunda humiditates extraneae corruptae quae aggregantur in radicibus capillorum. Uerumtamen caluitium quod ex priuatione humiditatis nutritiuae sit, curationem non habet. Et hoc quidem est simile eis qui plantantur et plantis quae exiccantur, quare non redeunt propter priuationem terrae suae.

At uero alopecia et tyria ueniunt ex corruptione humorum.

Et tyria quidem est difficilioris sanationis, quam alopecia; Sed sunt utraque generis unius quando consideras sollicite causam facientem utramque euenire Et non dissentiunt nomina utrorumque nisi ex parte figurae. Quod est quia tyria non apparet in capite et reliquo corpore nisi sicut serpens. et eueniunt cortices ei sicut cum excoriatur serpens. Alopecia uero non nominatur taliter nisi quoniam accidit uulpibus semper. Et quando diligenter attendis causam facientem euenire utramque simul inuenis ambas unius speciei, sed sunt diuersae in actione et nomine: in actione quidem quoniam tyria est difficilior ad sanandum quam alopecia; sed in nomine quoniam haec nominatur tyria ex figura serpentis, et spolio cutis eius. Et nominatur alopecia quoniam accidit uulpibus multotiens.

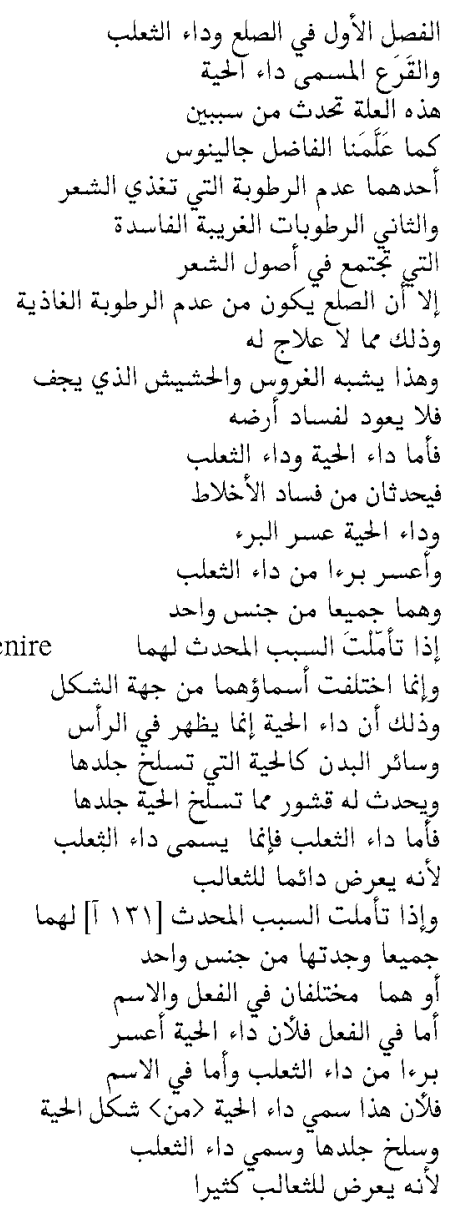

Translation of the Arabic: The first chapter on baldness ( sala'), alopecia

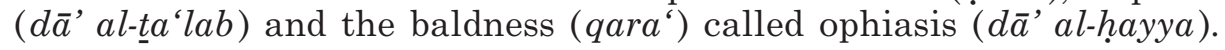

${ }^{50}$ I shall propose a different argument below, pp. 251-2.

${ }^{51}$ Ea fols. 130b5-131a4; lat. G (fol. 2ra ult. ff.). 
This disease occurs for two reasons, as the excellent Galen taught us $^{52}$ : Firstly because of lack of moisture nourishing the hair. Secondly, the accumulation of unnatural and corrupting moistures that gather at the roots of the hairs, even though baldness (sala ${ }^{\prime}$ ) occurs because of lack of moisture nourishing the hair, and for that there is no cure. This is similar to plants and herbs which, once dried out, do not recuperate because the soil is corrupted. The corruption of humours causes the diseases called ophiasis and alopecia, but ophiasis is difficult to cure, more difficult than alopecia. They both belong to the same category, if you consider well what causes them, although their names are different with regard to form, since ophiasis has the appearance, on the head and the rest of the body, of a snake shedding its skin; and by this means, scaling occurs, which is similar to the skin shed by the snake. Alopecia is called thus because it often occurs in foxes. If you consider well what causes them, you will find them to be of the same category; yet they differ in action and in name: in action, since ophiasis is more difficult to cure than alopecia; or in name, since this is called ophiasis because of the form of the snake and the shedding of its skin. Alopecia is called thus because it occurs frequently in foxes.

As far as we can tell from this comparison, there are no significant differences between the two texts. Yet there is one feature which singles out the version contained in Ea. In Ea, the term for "chapter" is fasl, not $b \bar{a} b$ as in all the other versions which have come down to us. ${ }^{53}$ So although Ea is notably different in one respect from the other versions, it does not differ greatly from lat. $\mathbf{G}$ on the level of content. We have seen above that the additions in $\mathbf{B}$ (compared to the text in $\mathbf{L}$ ) did not have a Latin equivalent in lat. G. Since Ea follows lat. $\mathbf{G}$ faithfully, then whatever additions are referred to on the title page of $\mathbf{E a}$ are not those contained in $\mathbf{B}$. To put it differently: when comparing $\mathbf{B}$ with $\mathbf{L}$ and lat. $\mathbf{G}$, we found that $\mathbf{B}$ has phrases not contained in lat. G. Since there is no such divergence between Ea and lat. G, we can be confident that the additions by Bar Bahlūl allegedly contained in Ea are not the additions encountered in $\mathbf{B}$.

We will come back to this first chapter of Ibn Sarābiyūn's work later, when discussing the similarities and differences between the Small and Large Compendium. Before tackling the problem of the different translations of the Small Compendium

\footnotetext{
${ }^{52}$ Galen, De compositione medicamentorum secundum locos (12.381, 11 Kühn), in

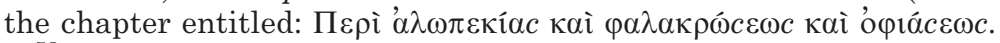

${ }^{53}$ In $\mathbf{E b}$, the term for "chapter" does not occur.
} 
in greater detail, we need to examine the second Escorial manuscript discussed by Troupeau, namely Eb. It consists of only one leaf and is written in an Andalucian hand; it is bound together with other medical writings by 'Alī ibn Riḍān and Hunayn ibn Ishāq. ${ }^{54}$ The relatively short fragment is interesting, since it allows us to compare it with the quotations contained in the Kitāb al-Fāhir by Pseudo-Rāzī, ${ }^{55}$ which is another important piece needed to solve the puzzle of the different translations.

Eb, fol. 39a, -7-39b6

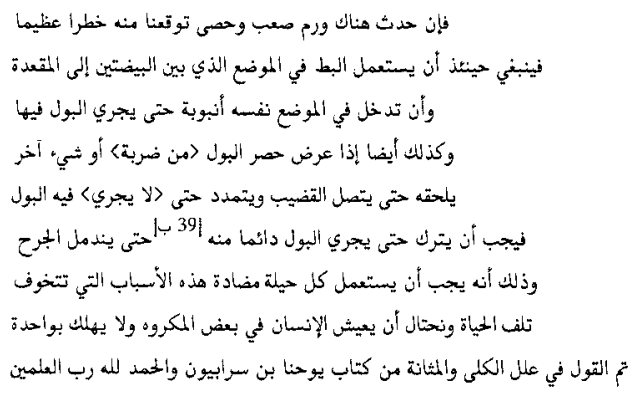

Kitāb al-Fāḩir, ed. Koning, p. 122, 5 -ult. ${ }^{56}$

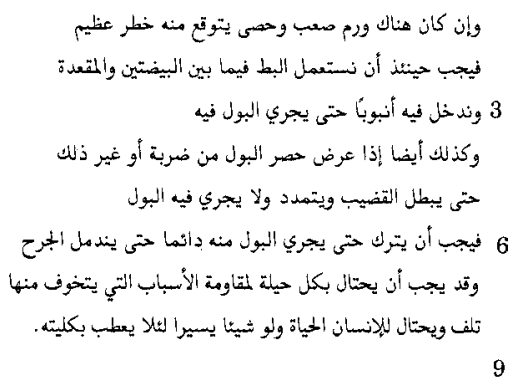

Translation of Eb: If a hard swelling and stones occur, we can expect a great danger. In this case, one ought to make an incision in the area between the testicles down to the anus, and introduce into this same place a tube so that the urine flows into it. Likewise, if retention of urine occurs because of a blow, or something else is obstructing it [sc. the urine], to the extent that the penis does not function and is erect so that urine cannot flow through it, then we ought to leave it until the urine flows constantly from it [sc. the penis], so that the wound may heal. For it is necessary to use every method counteracting these causes from which loss of life is feared, and to strive that the patient live, [even if it be] in some dreadful state, and do not perish completely. This is the end of the discussion on the diseases of the kidneys and the bladder from Yūhannā ibn Sarābiyūn's book. Thanks be to God, Lord of the universe.

${ }^{54}$ Cf. Derenbourg, Renaud, Les manuscrits arabes de l'Escurial, 2.2, 59-60.

55 The Kitāb al-Fāhir is not by al-Rāzī, as some scholars have often assumed. L. Richter-Bernburg ("Pseudo-Tāabit, Pseudo-Rāzī, Yuhannā ibn Sarābiyūn”) has shown conclusively that this attribution is incorrect and should definitively be abandoned; Troupeau ("Du syriaque ...", p. 276), who assumed that Kitāb al-Fāhir was composed by al-Rāzī, already compared the two versions.

${ }^{56}$ P. de Koning, Traité sur le calcul dans les reins et dans la vessie (Leiden, 1896). 
The two versions differ considerably on the level of expression and language employed. Small differences include the following: in line 2, Eb has fa-yanbagī where Kitāb al-Fāhir has fa-yağibu; line 4 šay'in ăhara vs gayri dālika; line 6 d̄ā'iman minhu vs minhu dā'iman. Sometimes, Kitāb al-Fāhir departs more substantially from $\mathbf{E b}$, as is the case in lines 7-8 (line 9 not lending itself to comparison). Yet on the level of content, there is hardly any differences. The question now arises whether Kitāb al-Fāhir represents a different version of Ibn Sarābiyūn's Small Compendium, or whether the discrepancies can be explained in terms of pseudo-Rāzi having quoted his source more loosely. U. Weisser has shown that al-Rāzī in his $K i t \bar{a} b a l-H \bar{a} w \bar{\imath}$ is not always faithful to his source; in not a few cases, he strongly paraphrases rather than cites verbatim. ${ }^{57}$ The same could be true for the author of Kitāb al-Fāhir. The last sentence (lines 7-8) is quite different in the two versions. The Latin rendering by Gerard of Cremona (lat. G) runs as follows: ${ }^{58}$

Si autem accidit illic apostema difficile et times ex ipso timorem magnum, tunc oportet ut administremus perforationem in loco qui est inter testiculos et anum, et intromittas in locum ipsum cannulam, et faciamus ut currat urina in ea. et similiter etiam quando accidit expressio urinae ex percussione aut ex re alia quae sequitur ipsum donec attrahatur cannula uirgae, et attrahatur donec non currat in ea urina. tunc oportet ut perforetur, et dimittatur cannula donec sanetur illud quod in circuitu est loci, et fit sursus urinae assiduae ex ea. Quod est quia oportet ut administremus omni ingenio ea quae contraria sunt istis causis ex quibus timetur perditio uiuorum et eligamus ut uiuat homo in qualibet parte mali et non moriatur statim subito.

While Eb has wa-d̄alika annahu (this is because), Kitāb al-Fāhir has the simpler wa-qad; lat. G sides with Eb: Quod est quia. Likewise, for the rest of the sentence, lat. $\mathbf{G}$ follows the diction of Eb much more closely than Kitāb al-Fāhir. On the other hand, there are instances where $\mathbf{E b}$ and Kit $\bar{a} b$ al-Fāhir together side against lat. G. In line 1, for example, both $\mathbf{E b}$ and Kitāb al-Fāhir have the juncture waramun sa'bun wa-hașan (a hard swelling and calculi), while lat. G only says apostema

${ }^{57}$ U. Weisser, "Zitate aus De methodo medendi im $H \bar{a} w \vec{\imath} \vec{\imath}$, in G. Endress, R. Kruk (eds.), The Ancient Tradition in Christian and Islamic Hellenism (Festschrift Drossaart Lulofs), (Leiden, 1997), pp. 279-318.

58 (Venice, 1525), fol. 19ra26 ff. 
difficile (a hard swelling), thus omitting to translate wa-hasan (and calculi). This analysis may suggest two things: (1) the author of Kitāb al-Fähir had in front of him a version of the Small Compendium which was closer to Eb than to the Arabic source of lat. G; and (2) the author of Kitāb al-Fāhir took some liberties when citing his source, sometimes paraphrasing it, although generally being quite faithful. In that sense, PseudoRāzī's attitude is in keeping with that of al-Rāzi described by U. Weisser.

Ullmann, Richter-Bernburg, and Troupeau all tackled aspects of the question of what to make of the many quotations in Rāzī's Kitāa al-Ḥāwi taken from Ibn Sarābiyūn. ${ }^{59}$ Ullmann, followed by Richter-Bernburg, ${ }^{60}$ for instance, speculated whether some of the quotations in Rāzì's Hiâwi come from the Large rather than the Small Compendium, since the quotations in Rāzì's Hạ $w \bar{\imath}$ deviate from the text of the Small Compendium contained in B. ${ }^{61}$ We can be sceptical as to whether Rāzì's $H \bar{a} w \bar{\imath}$ as Troupeau claimed, ${ }^{62}$ is closer to lat. $\mathbf{G}$ than e.g. P. We have seen above that $\mathbf{B}, \mathbf{E a}, \mathbf{E b}$ are all, despite certain small variations, quite similar to the presumed source of lat. $\mathbf{G}$. That this is also the case for $\mathbf{P}$ will be demonstrated in the following.

$\mathbf{P}$ is yet another fragment of the Small Compendium, also bound together with other medical texts. ${ }^{63}$ It contains a number of errors, as Troupeau rightly notes. ${ }^{64}$ One chapter, that on jaundice (IV 9), is entirely preserved in this manuscript. It offers us the possibility to compare the Latin translation with the Arabic contained in $\mathbf{P}$ and two different versions which occur in Rāzì’s Hị̂̄wi :

${ }^{59}$ Kitāb al-Ḥāwi fī al-țibb, 1st ed., 23 vols. (Hyderabad, 1955-70); 2nd ed. (Hyderabad, 1974 ff.; repr. Beirut, 2000).

${ }^{60}$ Ullmann, "Sarābiyūn”, pp. 290-1, Richter-Bernburg, "Pseudo-T̄ābit, PseudoRāzī, Yuhannā ibn Sarābiyūn”, pp. 74-7.

${ }^{61}$ I will return to this point in the third part of the present contribution, when discussing the relationship between the Small and the Large Compendium.

${ }^{62}$ Troupeau, "Du syriaque ...", p. 273: "Quant à la traduction latine de ce fragment par Gérard de Crémone ... elle semble plus proche de la citation d'al-Rāzì que du texte du manuscrit de Paris".

${ }^{63}$ Cf. MacGuckin Le Baron de Slane, Bibliothèque Nationale. Département des manuscrits. Catalogue des manuscrits arabes (Paris 1883-95), p. 522.

64 "Du syriaque ...", pp. 275-6. 
lat. G

Rāzī Ḥāwī 7.157, ult. (a) Rāzì Ḥāwī 7.168, 8 (b)

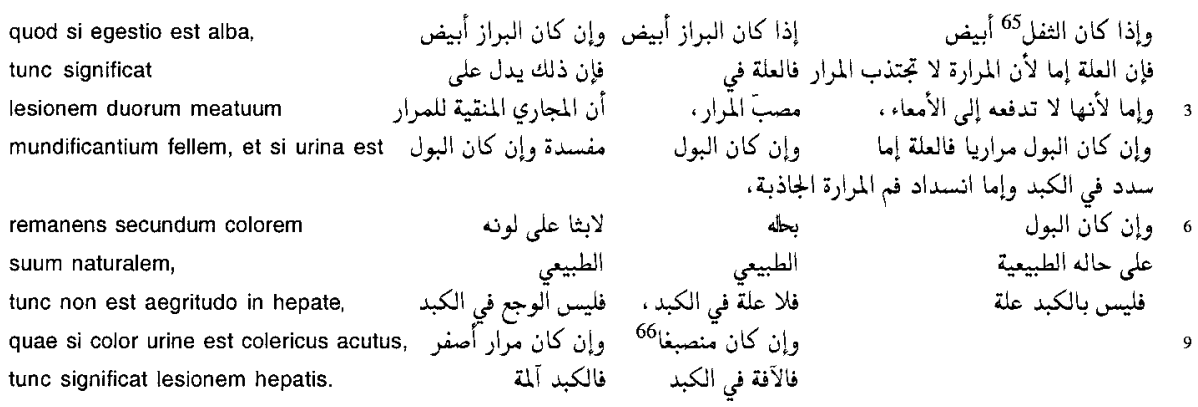

This synoptic table is illuminating in many respects. First of all it shows that al-Rāzi himself will change the text of the quotation for no apparent reason. In line 1 , both $\mathbf{P}$ and Rāzi $H \bar{a} \bar{w} \bar{\imath}$ (a) have birāz (faeces) while Rāzī Hị̂w (b) has tufl (dregs), that is to say, he replaces a term with a synonym. In line 2, Rāzi $H \bar{\alpha} w \bar{\imath}$ (a) is similar to $\mathbf{P}$ on the level of content, but paraphrases rather than cites its source; for instance the expression al-mağāri al-munaqqiyyatu li-al-marāri (the passages which cleanse the bile) in $\mathbf{P}$ is changed into masabb al-marār (the outlet of the bile) in Rāzì Hā $w \bar{\imath}$ (a), while in Rāzī $H \bar{a} w \bar{\imath}(\mathrm{b})$ he changes the overall meaning. Line seven contains another example of al-Rāzī's changing the passage for no apparent reason other than fondness for variation: $\mathbf{P}$ has fa-laysa al-wağa'u fī al-kabidi while al-Rāzī says fa-lō 'illata fī al-kabidi 'illatun (a) and fa-laysa bi-al-kabidi 'illatun (b). The second conclusion to be made when comparing the different versions is the fact that lat. $\mathbf{G}$ is closer to $\mathbf{P}$ than either quotation in al-Rāzì. To pick just one example, in line 2 , the text in $\mathbf{P}$ fa-inna dālika yadullu 'alā anna (this indicates that) is translated in lat. $\mathbf{G}$ as tunc significat (then it indicates), while the idea of "indicating" is absent from both versions in al-Rāzì.

Let us now return to the original question: can we match Ibn Abi Ușaybi'a's account of the different translators with the conclusions drawn from the different versions just discussed Both Ea and $\mathbf{L}$ claim to be translated by al-Hadītī although in the case of the former, Bar Bahlūl seems to have revised

65 correxi.

${ }^{66}$ In lines 7-8, this is the reading of the second edition, also reproduced in the Beirut reprint (see above n. 59); the first edition has فليس الآفة في الكبد. 
al-Hadītīs version. $\mathbf{L}$ and $\mathbf{B}$ are for the most part identical, although $\mathbf{B}$ sometimes has additions or variant readings different from both $\mathbf{L}$ and lat. $\mathbf{G}$. In general, $\mathbf{B}, \mathbf{E a}, \mathbf{E b}, \mathbf{L}$, and $\mathbf{P}$ all agree on the level of content with lat. $\mathbf{G}$, although $\mathbf{B}$, as mentioned before, sometimes has small additions. There is one fundamental difference between Ea on the one hand and $\mathbf{B}, \mathbf{L}$ and $\mathbf{P}$ on the other: the former refers to the chapters in the book as fușūl (sg. fașl), while the latter call them $a b w \bar{a} b$ (sg. $b \bar{a} b)$. $\mathbf{P}$ has numerous scribal errors, while the overall quality of the other manuscripts is somewhat better. Furthermore, Pseudo-Rāzì, the author of Kitāb al-Fāhir, and al-Rāzì in his Kitāb al-Ḥāwi both quote from an Arabic version, but when doing this, take certain liberties both at the level of expression as well as content. Kitāb al-Fähir can side with Eb against lat. G.

Ibn Abī Ușaybi'a said that there were three translations. That by al-Hadīî made in the year 930, was allegedly more idiomatic than that by Bar Bahlūl.67 Ibn Ab̄̄ Ușaybi‘a also mentions another translation by Abū Bišr Mattā. I would like to propose the following argument. Let us assume that Ea contains the translation by Bar Bahlūl, and not that by al-Hadītī. Al-Hadītī is mentioned as the translator only on the title page (fol. 129a) of Ea, and not at the beginning of the treatise itself (fol. 129b). Dr Álvarez-Millán ${ }^{68}$ confirmed through autopsy what Troupeau ${ }^{69}$ already stated, namely that the title on the recto and the beginning of the treatise on the verso are by the same scribe. But there are inconsistencies between the title (fol. 129a) and the beginning (fol. 129b): the title, for instance, refers to Bar Bahlūl incorrectly as "Ibn al-Bahlūl" while the beginning has the standard "Ibn Bahlūl". This inconsistency could be explained in the following terms: while the scribe copied the beginning of the treatise from a reliable manuscript, he may have added the title under his own steam or produced it from a different, unreliable source.

Additionally, if we accept that $\mathbf{L}$ contains the translation by al-Hadīî as indicated in the manuscript, we could explain the difference in referring to "chapter" as fașl and $b \bar{a} b$ respectively

\footnotetext{
67 See above pp. 239-40.

${ }^{68}$ I would like to thank Dr Álvarez-Millán for inspecting the manuscript

69 “Du syriaque ...”, p. 272.
} for me. 
in the two manuscripts by the fact that $\mathbf{L}$ was translated by someone else other than Ea. Furthermore, on the level of content, both translations, that by Bar Bahlūl (Ea) and that by al-Hadītī (L), resemble each other quite closely, as can be seen from the fact that they are similar to lat. G. There is, however, another unsolved question: what translations did al-Rāzī and Pseudo-Rāzī use In the case of al-Rāzī, it cannot have been the version by al-Hadītī for chronological reasons, as Richter-Bernburg argued: al-Rāzī died 925, and al-Ḥadītī translated the Small Compendium in $930 .{ }^{70}$ On the other hand, we know that Bar Bahlūl must have been active around the year 963, because Mārī ibn Sulaymān writes in his book on the Nestorian Patriarchs that Bar Bahlūl recommended 'Abd İšu' for the office of the patriarch.71 That makes it highly unlikely that al-Rāzī used Bar Bahlūl's version, and if we assume that there were only the three mentioned by Ibn Abī Ușaybi'a, then it follows that al-Rāzī used that by Abū Bišr Mattā (d. 940). Ullmann compared al-Rāzī with $\mathbf{B}$ and concluded that, apart from relatively small discrepancies, the two versions go back to the same source, that is two say, represent the same translation. ${ }^{72}$ However, if $\mathbf{B}$ contains the same translation as $\mathbf{L}$ (with some additions), if $\mathbf{L}$ consists of al-Hadītî̀s translation and if this translation was produced in 930 (with emphasis on the "ifs"), then Ullmann must be incorrect for the chronological reasons mentioned above.

In order to illustrate the similarities and differences between the two texts, and in order to determine what source was used by Ibn Sarābiyūn in the chapter "On Snakebites", I offer the following synoptic table:

${ }^{70}$ Richter-Bernburg, "Pseudo-T̄ābit, Pseudo-Rāzī, Yuhannā ibn Sarābiyūn”, pp. 68-9.

${ }^{71}$ H. Gismondi, Maris Amri Slibae De Patriarchis Nestorianorum Commentaria, 2 vols. (Rome, 1899), vol. 1, 1.1 (txt.), 89 (tr.):

$$
\text { وذكر أبو الحسن ابن البهلول أسقفَ معلثايا وأنه من القوم الذين يصلحون للمئاسة }
$$

(Abū al-Ḥasan ibn Bahlūl mentioned the bishop of Ma'latāyā [saying] that he is apt for the office of the patriarch.)

${ }^{72}$ Ullmann, "Sarābiyūn”, p. 290: “... da die Texte in der Hauptsache doch übereinstimmen, sollte man annehmen, daß al-Rāzī dieselbe Übersetzung ausgeschrieben hat, die uns in der Brüsseler Handschrift erhalten ist." 

1) lat. $\mathbf{G}$ fol. $52 \mathrm{vb}-5$
2) PAeg. ii. $16,1-17,8$
3) $\mathbf{B}$ fol. $17 \mathrm{~b}-6$
4) $\mathrm{R}<\mathrm{S}$
5) $\mathbf{R}<\mathbf{P}^{73}$

De morsu viperarum

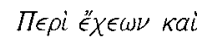

masculinarum et femi- $\epsilon^{\prime} \chi \delta \nu \omega \omega \nu$.

narum. Caput xx.
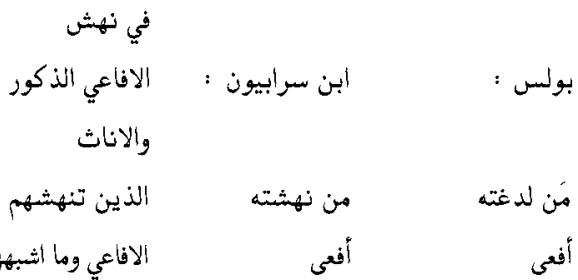

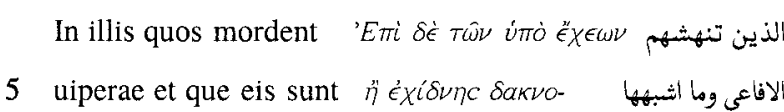

$$
\text { الذين تنهشهم }
$$

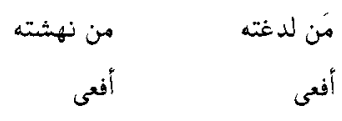

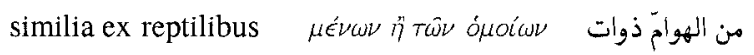

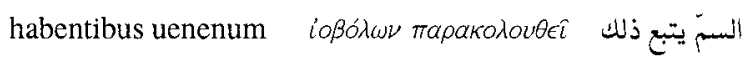

فإن الوجع

عرض لم وجع

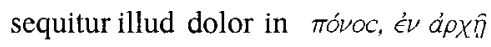

الوجع اولا

يحدث بدنا في

primis in ipso loco

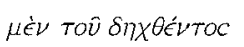

في نفس الموضع

موضع النهشة

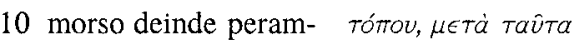

المنهوث ثم يدب

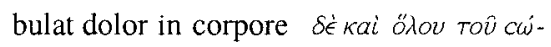

الموجع في البدن

toto, et apparent in

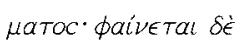

كله، ويظهر في توي

وبعد ذلك يدب

في الجسسد كله

ويكون في موضع

loco duo foramina

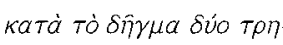

الموضص ثقبان

النهشة ثقبتان

في

propinqua ex quibus

متقاربان يجري

غير متباعدتين،

موضع النهشة

ثم يدبّ وجعه

في جميع ، البدن

وترى في موضع

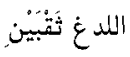

15 currit sanguis et

humiditas uirulenta

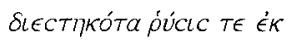

منهما دم

ويسيل منهما

مفترقين قليلا كل

тоит $\omega \nu$ alıatoc kai

ورطوبة

صديد

يسيل منهما دم

ورطوبة ثبه مائية

oleagina

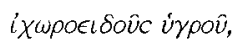

صديدية

وبعد هذا رطوبة

الدم ثم يسيل هنها تهاتها

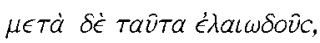

دهنية وثم رطوبة دهنية،

رطوبة زيتية ثم

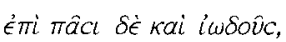

رطوبة زبجارية ، تثبه الصديد

The first column contains the Latin translation by Gerard, the second the beginning of the chapter "On snakes" taken from Paul of Aegina's $\pi \rho \alpha \gamma \mu \alpha \tau \varepsilon i \alpha,{ }^{74}$ the third the Arabic version contained in B, and the forth al-Rāzì's quotation from Ibn Sarābiyūn $(\mathbf{R}<\mathbf{S})$ and the fifth al-Rāzì's quotation from the Arabic translation of Paul of Aegina $(\mathbf{R}<\mathbf{P})$. As we have seen before and as Ullmann is right to insist, al-Rāzī often changed his source text, so that it is difficult to determine whether the differences are due to his altering the version from which he quotes, or to his using a different translation. We can surely say that, on the level of content, $\mathbf{R}<\mathbf{S}$ and $\mathbf{B}$ are quite similar, with

73 B has previously edited by Ullmann, ibid. p. 285, §§ $1-3 ; \mathbf{R}<\mathbf{S}$ is taken from

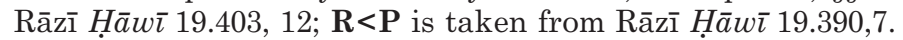

74 Ed. I. L. Heiberg, CMG 9.1-2, 2 vols. (Leipzig and Berlin, 1921/1924). 
only slight omissions (e.g. lines $4-5$ ) and variations. On the level of language, things are more complicated.

Ibn Sarābiyūn used Paul of Aegina as his source in this chapter, as in a number of other instances when dealing with toxicology and gynaecology. ${ }^{75}$ I put $\mathbf{R}<\mathbf{P}$ into the synoptic table in order to be able to check the differences between $\mathbf{R}<\mathbf{S}$ and $\mathbf{B}$ against $\mathbf{R}<\mathbf{P}$, that is to say against quotations which come from a completely different translation. The question is: are the differences between $\mathbf{R}<\mathbf{P}$ and $\mathbf{B}$ greater than those between $\mathbf{R}<\mathbf{S}$ and $\mathbf{B}$. The answer must be: only marginally. In line 3 , for instance, $\mathbf{R}<\mathbf{S}$ uses the same verb as $\mathbf{B}$ for "to bite" (nahaša), while $\mathbf{R}<\mathbf{P}$ employs a different one (ladag்a), though in the latter case the tense is different (tanhašuhum vs. nahašathum). On the other hand, in line $8 \mathbf{R}<\mathbf{P}$ sides with $\mathbf{B}$ (tumma for "there"), while $\mathbf{R}<\mathbf{S}$ has $b a^{\prime} d a d \bar{a} l i k a$ ( similar line 14). In some cases, the fact that $\mathbf{R}<\mathbf{S}$ and $\mathbf{R}<\mathbf{P}$ agree against $\mathbf{B}$ illustrates a certain linguistic preference of al-Rāzī; take, for instance, the use of man instead of alladi as relative pronoun (line 3). Therefore, the comparison of $\mathbf{R}<\mathbf{S}$ and $\mathbf{B}$ is inconclusive as to whether the two are based on the same translation. This means that, despite Ullmann's cautious assumption that $\mathbf{R}<\mathbf{S}$ is based on the same source as $\mathbf{B}$, it is more likely that al-Rāzī quoted from Abū Bišr Mattā's translation.

Let me now draw some tentative conclusions about the translations: Ea contains Bar Bahlūl's translation of the Small Compendium. $\mathbf{L}$ is based on al-Hadītī's version, as is $\mathbf{B}$, although the latter sometimes has additions and variant readings, not contained in lat. G. At this point, we cannot ascertain on which translation $\mathbf{P}$ and $\mathbf{E b}$ are based. Be that as it may, on the level of content, all the manuscripts discussed here are generally speaking very similar to each other as can be seen from the fact that they rarely deviate from lat. G. Al-Rāzi (Kitāb al-Hīw $\bar{\imath}$ ) and Pseudo-Rāzì (Kitāb al-Fāhir), when quoting from Ibn Sarābiyūn, rephrase and paraphrase, which makes it difficult to determine from which translation their quotations are taken. For chronological reasons, it seems likely that al-Rāzī quoted from the version by Abū Bišs Mattā, but for lack of a critical edition and analysis of the Kitāb al-Făhir, it is

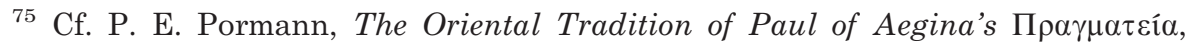
Studies in Ancient Medicine 29 (Leiden, 2004), pp. 21-2. 
impossible to determine with certainty which translation Pseudo-Rāzī used.

Ibn Abī Ușaybi'a said that the version by al-Hadītī is "more idiomatic" (ahsanu 'ibāratan) than that by Bar Bahlūl. Troupeau was surprised by this statement and declared that Ea is written in good Arabic. ${ }^{76}$ Yet, it appears that Ibn Abi Usaybi'a did not criticise the grammatical quality of Bar Bahlūl's translation but rather its style. For instance, one might qualify Bar Bahlūl's use of ru'ūs (sg. ra's) for "headings" as a syriacism (cf. 1e. ;7); in fact, the use of ra's for "chapter" is so unusual, that F.W. Zimmermann thought it odd. ${ }^{78} \mathrm{Bar}$ Bahlūl, in his glossary, also gives as the standard translation

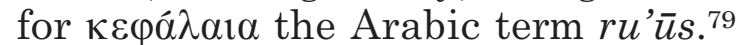

The Latin rendering by Gerard of Cremona (lat. G) was translated into Hebrew by Mōšē ben Mazliah and is extant in Oxford, Bodleian MS Mich. 207 (Ol. 569).80 Furthermore, Andreas Alpago reworked lat. G, although his revision often does not go much beyond orthography. ${ }^{81}$ Since his translation is based on lat. $\mathbf{G}$, which is extant, one should always use lat. G when trying to recover the original Syriac or the Arabic translation.

\footnotetext{
76 “Du syriaque ...”, p. 274: "La langue du traducteur [sc. Bar Bahlūl] ... est grammaticalement correcte et ... son expression ... n'est pas du tout mauvaise, ...".

77 Cf. C. Brockelmann, Lexicon Syriacum, 2nd ed. (Halle, 1928), p. 728a s.v. n. 8.

78 F. W. Zimmermann, "The origins of the so-called Theology of Aristotle", in J. Kraye et al. (eds.), Pseudo-Aristotle in the Middle Ages: The Theology and Other Texts (London, 1986), pp. 110-240, p. 170: "As a translation of kephalaia, ru'ūs would be a Graecism or Syriacism"; but cf. P. E. Pormann, "The Alexandrian Summary (Ğawāmi') of Galen's On the Sects for Beginners: Commentary or Abridgment", in P. A. Adamson et al. (eds.), Philosophy, Science and Exegesis in Greek, Arabic and Latin Commentaries, 2 vols. (London, 2004) [forthcoming].

${ }^{79}$ Lexicon Syriacum, ed. Duval, col. 1823, 15:
}

\section{مقلا أس ص: مز0;}

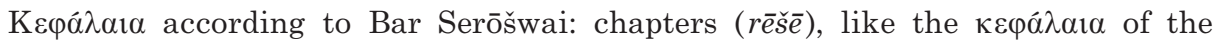
blessed Marc; chapters (ru'ūs).

${ }^{80}$ Cf. Ullmann, "Sarābiyūn", p. 282; Troupeau, "Du syriaque ...", p. 273; A. Neubauer, Catalogue of the Hebrew Manuscripts in the Bodleian Library (Oxford, 1886), no. 2087.

${ }^{81}$ Cf. Troupeau, ibid.; this translation was printed posthumously as Serapionis ... Practica studiosis medicinae utilissima quam postremo Andreas Alpagus Bellunensis ... in latinum convertit: cujus translatio nunc primum exit in lucem (Venice, 1550); for a more general appreciation of Alpago, see F. Lucchetta, Il medico e filosofo bellunese Andrea Alpago († 1522), traduttore di Avicenna; profilo biografico (Padua, 1964). 
Before coming to the Large Compendium, it is necessary to add a caveat. I called my conclusions "tentative" for at least two reasons: first of all, because they are based on attributions of translations in manuscripts and the bio-bibliographical tradition. G. Endress, D. Gutas and M. Ullmann have amply demonstrated that these attributions are often fictitious, and that one should therefore be cautious not to take them at face value. ${ }^{82}$ Second, we dealt for the most part with unpublished texts here; once the fragments of the Small Compendium, including the fragments in the Kitā $b$ al-Fāhir, are edited, a new picture might emerge. This said, the conclusions drawn above seem relatively probable and can serve as a hypotheses which future scholarship will have to test.

\section{III}

We have seen that scholars speculated about the relationship between the Small and the Large Compendium. Is the former just an abbreviated version of the latter? Can the quotations in al-Rāzì which deviate from the Small Compendium be explained as al-Rāzī having employed the Large Compendium? Until F. Sezgin published the Istanbul, Kütüphane Süleymaniye, MS Aya Sofya 3716 in facsimile, scholars thought that this manuscript contained the Large Compendium. ${ }^{83}$ In reality, it is the medical aide-mémoire of a tenth-century Baghdad physician called al-Kaskarī. ${ }^{84}$ Yet, within this work by alKaskarī, there are a number of quotations from the Large Compendium, which constitute the only fragments explicitly attributed to this work. In the following, I shall present the

${ }^{82}$ G. Endress, D. Gutas (eds.), A Greek and Arabic Lexicon (Leiden etc., 1992 ff.), vol. 1, pp. 8*-9*; G. Endress, "Die griechisch-arabischen Übersetzungen und die Sprache der arabischen Wissenschaften", in Symposium Graeco-Arabicum II (Amsterdam, 1989), pp. 103-46, p. 110; reprinted in slightly modified form as: "8.7 Die Entwicklung der Fachsprache", in W. Fischer (ed.), Grundriß der Arabischen Philologie, 3 vols. (Wiesbaden, 1982-92), vol. 3, p. 6. M. Ullmann [Wörterbuch zu den griechisch-arabischen Übersetzungen des 9. Jahrhunderts (Wiesbaden, 2002)] recently and brilliantly gave an excellent example of the confusion as to who translated Galen's On the Powers of Simple Drugs into Arabic; cf. JRAS, 13.1 (April 2003): 105-7.

${ }^{83}$ F. Sezgin, Book On Medicine. Kunnāš by Ya'qūb al-Kaškarī, Publications of the Institute for the History of Arabic-Islamic Science, Series C, vol. 17 (Frankfurt, 1985); cf. P. E. Pormann, "Theory and practice in the early hospitals in Baghdad - Al-Kaškarī On Rabies and Melancholy", Zeitschrift für Geschichte der Arabisch-Islamischen Wissenschaften, 15 (2003): 197-248.

${ }^{84}$ Pormann, ibid., pp. 199-202. 
reader with an edition and translation of the opening of the most important fragment, namely that on capillary disorders. ${ }^{85}$ This will lead to a comparison with a similar fragment from the Small Compendium already discussed. Finally, I will address some more global questions about Ibn Sarābiyūn and his work.

At the beginning of his aide-mémoire, al-Kaskarī quotes an entire chapter from Ibn Sarābiyūn's Large Compendium:

$$
\begin{aligned}
& \text { الباب الأول من هذا الكتاب في تولد الشعر في سائر البدن من كناش ابن سرافيون الكبير ثلثة عشر } \\
& \text { مقالة } \\
& \text { (1) لما كان غرضنا أن نذكر الآفات العارضة للشعر فيجب علينا أولا أن نطلب السبب المولّد للشعر }
\end{aligned}
$$

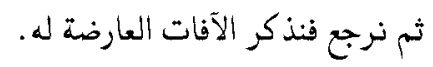

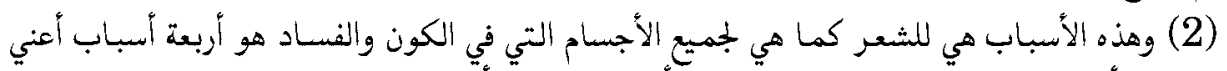

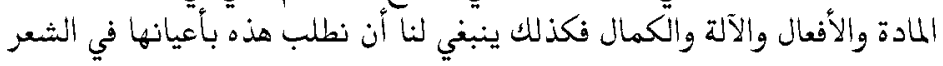

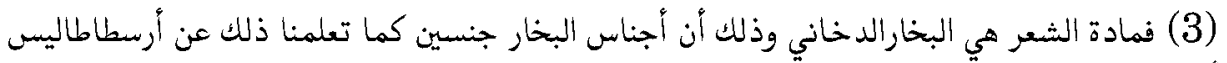

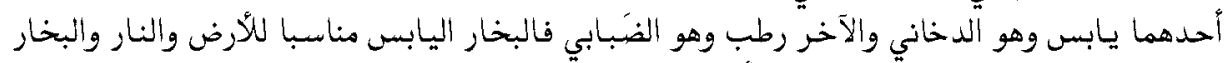

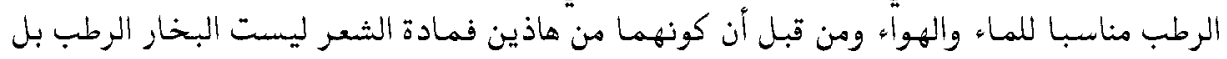

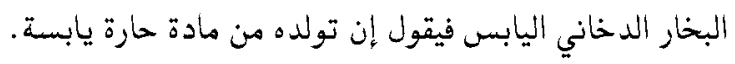

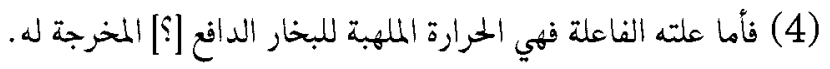

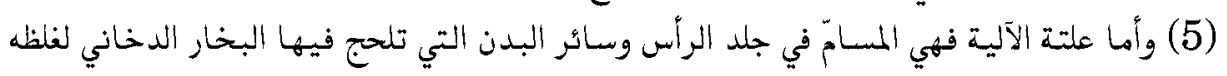

$$
\begin{aligned}
& \text { فيتلبد ويصلب فيصير شعرا. }
\end{aligned}
$$

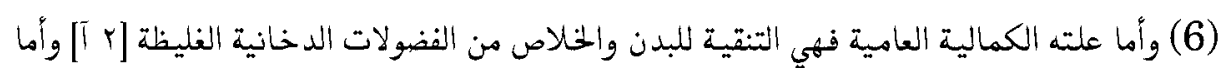

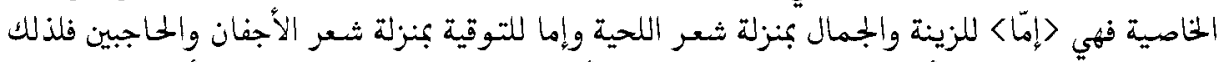

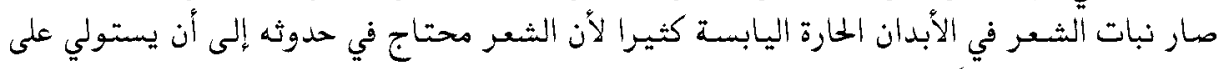

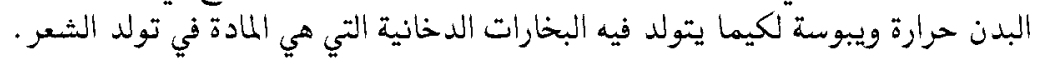

Translation:

The first chapter of this book on the generation of hair over all [s $\left.\bar{a}^{\prime} i r\right]^{86}$ the body, from the Large Compendium by Ibn Sarāfiyūn, [comprising] thirteen books [maqālas].

1. Since we aimed at discussing forms of harm befalling hair, we ought first of all to investigate the cause which generates it [hair].

85 Preserved at the beginning of the treatise on fol. $1 \mathrm{a}$; the other quotations in this manuscript are found on fols. 54b8; 55b7; 85a-7; $135 \mathrm{a}-6$.

86 For this use of $s \bar{a}$ 'ir in the sense of "all" cf. W. Wright, A Grammar of the Arabic Language, 2 vols., 3rd ed. (Cambridge, 1896), vol. 1, p. 206D; R. Dozy, Supplément aux dictionnaires arabes, 2 vols. (Leiden, 1881), vol. 1, p. 621a (s.v.), E. W. Lane, Arabic-English Lexicon (London, 1863-93), p. 1282c (s.v.). 
2. These causes for hair - like for all bodies subject to generation and corruption - are four: the matter [material cause], the effects [effective cause], the instrument [instrumental cause] and perfection [final cause]. Accordingly, we need to seek out these selfsame [four causes] in the case of hair.

3. The matter of hair is a smoky vapour. There are two kinds of vapour, as we learn from Aristotle ${ }^{87}$ : one is dry and is the smoky one, the other is wet and is the misty one. The dry vapour corresponds to earth and fire, while the wet vapour corresponds to water and air. Since the two [vapours] are generated by these two [elements], hair does not consist of wet vapour, but of dry smoky vapour. We can therefore say that hair is generated by warm and dry matter.

4. The effective cause is the heat which kindles the vapour pushing out [the hair] and brings it out.

5. The instrumental cause are the pores in the skin of the head and the rest of the body, in which the smoky vapour gets stuck because of its being [too] thick, so that is compacted, hardens and finally becomes hair.

6. The final general cause is the cleansing of the body and the purging of thick, vaporous superfluities. The specific cause is either for the embellishment and beauty, as for instance the hair of the beard; or for protection, as for instance in the case of the hair of the eyelids or the eyebrows. Therefore, the growth of hair in warm and dry bodies is strong, for the hair, in order to generate, requires that the body possess warmth and dryness, so that in it [sc. the body] smoky vapours be generated which are the matter of which the hair is made.

There is a problem with the alleged number of maqālas of which the Large Compendium consists. According to al-Kaskarī, they are thirteen, but Ibn al-Nadīm only talks of twelve. ${ }^{88}$ There is no obvious solution for this discrepancy, apart from supposing a scribal error (ثلثة عشر vs ثر انتي عشر ) or the possibility that a chapter was subdivided into two in al-Kaskarī's exemplar.

To this chapter on the causes of hair growth in the Large Compendium, there is no precisely corresponding chapter in the Small Compendium. The closest we get is the chapter edited above from Ea on baldness, ophiasis and alopecia (bk 1, ch. 1). In the extract from the Large Compendium, Ibn Sarābiyūn is

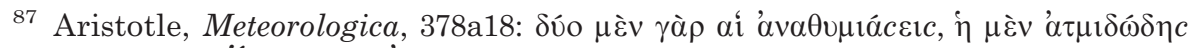

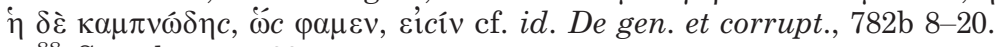

88 See above p. 234.
} 
quite concerned with causality. He first states that it is necessary to know the causes of a disease in order to treat it (1), and since each body has four causes, he will review them also in the case of hair (2). These causes are, of course, the four Aristotelian causes (material, efficient, instrumental and final). In $\S \S 3-6$, Ibn Sarābiyūn discusses each one of them in turn. When beginning to do so, the first authority invoked is Aristotle, not Galen. Later on in the chapter, he mentions Galen once, but only to say that the latter has taken a theory from the former. ${ }^{89}$ In the Small Compendium we also find a concern with causes: bk 1 , ch. 1 opens with the statement: "This disease occurs for two reasons [li-sababayn], as the excellent Galen taught us". But where the Large Compendium follows Aristotelian ideas, the Small Compendium relies on Galen. One might say that the former is more philosophical than the latter.

This combination of Aristotelian ideas with Galenic medicine is a specific feature of late antique Alexandria. In order to illustrate this statement, I would like to quote just one instance from its medical literature. Stephen of Athens, an author who wrote a number of commentaries on Hippocratic works, is probably the same as a philosopher by the name of Stephen, having lived in Alexandria in the 580s. ${ }^{90}$ Even if this Stephen cannot be identified with absolute certainty, he clearly relies on, and belongs to, the Alexandrian tradition. ${ }^{91}$ In his commentary on the Aphorisms, he links Hippocratic theory to Aristotelian philosophy ${ }^{92}$ :

89 Fol. 2b6:

$$
\text { وهذا الرأي أخذه جالينوس عن أرسطاطاليس لأنه ذكره في كتبه في الحيوان }
$$

(This theory [sc. about why hair turns white] Galen has taken from Aristotle for the latter mentions it [sc. this theory] in his books On Animals).

${ }^{90}$ Cf. W. Wolska-Conus, "Stéphanos d'Athènes et Stéphanos d'Alexandrie. Essai d'identification et de biographie", Revue des études byzantines, 47 (1989): 5-89; ead. "Les commentaires de Stéphanos d'Athènes au Prognostikon et aux Aphorismes d'Hippocrate: de Galien à la pratique scolaire Alexandrine", Revue des études byzantines, 50 (1992): 5-86.

${ }_{91}$ W. Wolska-Conus, "Sources des commentaires de Stéphanos d'Athènes, et de Théophile le Protospathaire aux Aphorismes d'Hippocrate", Revue des études byzantines, 54 (1996): 5-66.

${ }_{92}$ L. G. Westerink (ed.), Stephanus of Athens: Commentary on Hippocrates' Aphorism, i: Sections I-II, Corpus Medicorum Graecorum 11.1.3.1 (Berlin, 1985), p. 48,28 . The translation is that of Westerink with slight modifications. 


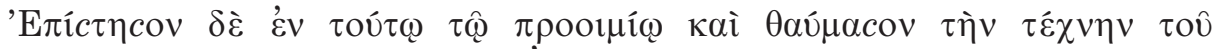

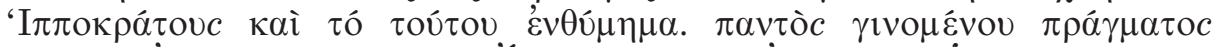

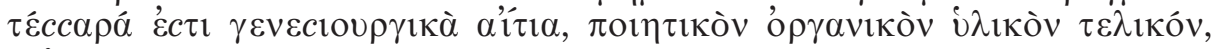
$\kappa \tau \lambda$.

Also worthy of notice and admiration in this preface is Hippocrates' technique and his way of reasoning. Everything which comes into being has four generating causes: an efficient, an instrumental, a material and a final cause, etc.

Thus we can immediately see the close link between the methods of describing natural processes in the Large Compendium and in Stephen of Athens's commentary: they both resort to the four causes; yet Stephen is by no means the only medical author to do so. A lot more could be said about this topic, as well as the intertwining of medical theory and philosophy, but space does not permit to explore it fully here. ${ }^{93}$

We can furthermore appreciate that the Large Compendium differs from the Small Compendium; not only is it the case that a whole chapter from the former has no exact equivalent in the latter, but they diverge also in their theoretical orientation. But does this initial comparison between the two texts allow us to ascertain whether authors such as al-Rāzī, when quoting from Ibn Sarābiyūn without reference to the exact work, used the Small or the Large Compendium, especially, where there is discrepancy between the quotation and the Latin translation of the Small Compendium? In general, one has to be sceptical, since there is always the possibility that the author citing Ibn Sarābiyūn is responsible for the change or the addition. In the case of al-Rāzī, this is quite likely, since he was notably careless with his sources and did not recoil form manipulating and rephrasing them. Moreover, al-Rāzī did not have the opportunity to put the final touch to his Kitāb al-Hīw $\bar{\imath}$, since it was compiled from notes following his death.

${ }^{93}$ Cf. J. Duffy, "Byzantine medicine in the sixth and seventh centuries: Aspects of teaching and practice", in J. Scarborough (ed.), Symposium on Byzantine Medicine, Dumbarton Oaks Papers 38 (1983), pp. 21-7, p. 22; M. Roueché, "Did medical students study philosophy in Alexandria?", Bulletin of the Institute of Classical Studies, 43 (1999): 153-69; P. E. Pormann, "Jean le Grammarien et le De sectis dans la littérature médicale d'Alexandrie", in I. Garofalo, A. Roselli (eds.), Galenismo e medicina tarcoantica: fonti greche, latine e arabe (Napoli, 2003), pp. 233-63, 251-2. 
At the end of this article, I would like to take up and discuss one other suggestion by H. Lehmann. ${ }^{94}$ Because of the extensive use of Greek and Syriac idioms, Lehmann advanced the hypothesis that Ibn Sarābiyūn might have been a Syro-Greek ("ein Syro-Grieche"); by this he meant that Ibn Sarābiyūn was of Greek origin, as one might also conjecture from the name of his father, Serapion, which is that of an old family of Greek doctors. Whether the name "Serapion" is a valid indication for Ibn Sarābiyūn's Greek origin remains doubtful. But the fragment from the Large Compendium above points in the direction of Alexandria. Ibn Sarābiyūn may or may not have known Greek, but he was certainly influenced by Greek medical theory as it was developed in Alexandria in late antiquity.

I have discussed the transmission of a medical text from Syriac into Arabic (and later Latin and Hebrew). Some of the questions posed by previous scholarship have been tentatively answered, and other problems put into better focus. Yet, the main task still remains in front of us: to edit the Arabic fragments of Ibn Sarābiyūn's Small and Large Compendium and, on the basis of such an edition, to discuss Ibn Sarābiyūn's place in the development of medical theory and practice in the ninth and tenth century. I am currently preparing such an edition, which will hopefully facilitate further research into this fascinating author. ${ }^{95}$

94 Contain in the letter already quoted (see above n. 38).

95 Peter E. Pormann, الكناشان الصغير والكبير لابن سرابيون (The Small and Large

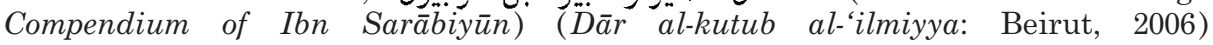
[in preparation]. 